\title{
A Bibliography on Cycling of Trace Metals in Freshwater Ecosystems
}

M.G. LaRiviere

A.J. Scott

W.G. Woodfield

C.E. Cushing

July 1978

Prepared for

the U.S. Department of Energy

under Contract No. EY-76-C-06-1830

Pacific Northwest Laboratory

Richland, Washington 99352 


\section{ACKNOWLEDGMENTS}

We would like to express our appreciation to Connie Connally for her editorial assistance in preparing this bibliography and to Harry George for his help in locating the references. This research was sponsored by the U.S. Department of Energy under Contract EY $-76-C-06-1830$. 


\section{FOREWORD}

In 1975 we began our studies of the cycling of trace metals in freshwater ecosystems. Concurrently, we began a literature search to determine the state-of-the-art in this field. We found that the topic of trace metals in the environment was, and still is, receiving a great deal of attention. It has been discussed at length in numerous recent symposia, and in open and in-house literature. Results of toxicity tests and data on environmental levels of trace metals are published most often. Interestingly enough, they seem to share the spotlight with studies on methods of measurement, indicating that there is some question about which methods are most reliable. One should therefore maintain a healthy skepticism toward published data in the field, giving attention to not only what is being measured and reported, but how it is being measured as well.

We were primarily interested in the literature directly addressing the cycling of trace metals in freshwater ecosystems. Data on cycling, including the influences of environmental mediators, are not nearly as abundant as the aforementioned information on environmental levels; there are, in fact, very few good papers on cycling.

This bibliography, then, is a listing of pertinent material we have found. Sot all citations deal exclusively with cycling; some discuss environmental measurements which may aid in interpreting cycling research. We have intentionally left out the extensive literature on the cycling of the radioactive isotopes of certain trace metals (e.g., $210 \mathrm{~Pb}$, $65 \mathrm{Zn}$, etc.) Several bibliographies, books, and symposia have al ready been published on the subject and are readily available.

Finally, this should be considered a working bibliography. It is not exhaustive because of the short time since its inception, but we hope that its content and the literature cited in these articles will be of use to others. 


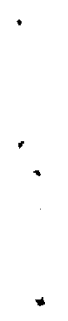




\section{A BIBLIOGRAPHY ON CYCLING OF TRACE METALS IN FRESHWATER ECOSYSTEMS}

1. Adams, F. S., H. Cole, Jr., and L. B. Massie. 1973. Element constitution of selected aquatic vascular plants from Pennsyivania: submerged and floating leaved species and rooted emergent species. Environ. Pollut. 5(2):117-147.

2. Albert, R., M. Berlin, J. Finklea, L. Friberg, R. A. Goyer, R. Henderson, S. Hernber g, G. Kazantzis, and R. A. Kehoe. 1973. Accumulation of toxic metals with special reference to their absorption, excretion, and biological half-times. Environ. Physiol. Biochem. 3(2):65-107.

3. Allan, R. J. 1975. Natural versus unnatura] heavy metal concentrations in lake sediments in Canada. Pages 785-808 in T. C. Hutchinson (ed.), Symp. Proc. International Conference on Heavy Metals in the Environment, Vol. II, Pt. 2. Institute for Environmental Studies, University of Toronto, Ontario.

4. Ande lman, J. B. 1973. Incidence, variability and controlling factors for trace elements in natural, fresh waters. Pages 57-88 in P. C. Singer (ed.), Trace metals and metal-organic interactions in natural waters. Ann Arbor Sci. Publ., Inc., Ann Arbor, MI.

5. Anderson, R. V. 1977. Concentration of cadmium, copper, lead and zinc in thirty-five genera of freshwater macroinvertebrates from the Fox River, Illino is and Wisconsin. Buil. Environ. Contam. Toxicol. 18(3): 345-349.

6. Andren, A. W., S. E. Lindberg, and L. C. Bate. 1975. Atmospheric input and geochemical cycling of selected trace elements in Walker Branch Watershed. ORNL-NSF-EATC-13. Oak Ridge National Laboratory, Oak Ridge, TN. $68 \mathrm{pp}$.

7. Angino, E. E., L. M. Magnuson, T. C. Waugh, and T. Evans. 1972. Partition coefficients for $\mathrm{Fe}, \mathrm{Mn}, \mathrm{Pb}, \mathrm{Ni}, \mathrm{Zn}, \mathrm{Cu}$ between river water and suspended load, and mineralogical composition of suspended load of selected Kansas river systems: Project completion report, July 69Dec. 70. Kansas Water Resources Institute, Manhattan, NY. 126 pp.
8. Atchison, G. J. 1975. Uptake and distribution of trace metals in fish. Water Resources Research Center, Purdue University, Lafayette, IN. $30 \mathrm{pp}$.

9. Ayling, G. M. 1974. Uptake of cadmium, zinc, copper, lead, and chromium in the Pacific oyster, Crassostrea gigas, grown in the Tamar River, Tasmania. Water Res. $8(10): 729-738$.

10. Barsdate, R. J. 1974. Pathways of trace elements in arctic lake ecosystems. NTIS, Springfield, VA. $87 \mathrm{pp}$.

11. Benes, P., and E. Steinnes. 1975. Migration forms of trace elements in natural fresh waters and the effect of the water storage. Water Resourc. Res. 9(3): 741-749.

12. Besch, W. K., M. Ricard, and R. Cantin. 1972. Benthic diatoms as indicators of mining pollution in the northwest Miramichi River system, New Brunswick, Canada. Int. Rev. Gesanten Hydrobiol. $57(1): 39-74$.

13. Bilinski, E., and R. E. Jonas. 1973. Effects of cadmium and copper on the oxidation of lactate by rainbow trout gills. J. Fish. Res. Board Can. 30(10): $1553-1558$.

14. Blaylock, B. G. 1974. Ecology and analys is of trace contaminants--progress report, January 1973-September 1973. NTIS, Springfieid, VA. $450 \mathrm{pp}$.

15. Blaylock, B. G., R. A. Goldstein, J. W. Huckabee, S. Janzen, and C. Matti. 1973. Ecology of toxic metals. Pages 121-160 in Ecology and analysis of trace contaminants, ORNL-NSF-EATC-1. Oak Ridge National Laboratory, Oak Ridge, TN.

16. Bowen, H. J. 1975. Residence times of heavy metals in the environment. Pages 1-19 in T. C. Hutchinson (ed.), Symp. proc. International Conference on Heavy Metals in the Environment, Institute for Environmental Studies, University of Toronto, Ontario. 
17. Boyd, C. E. 1970. Boron accumulation by native algae. Am. Midland Naturalist $84: 565-567$.

18. Boyd, C. E. 1970. Chemical analysis of some vascular aquatic plants. Arch. Hydrobiol. $67(1): 78-85$.

19. Boyd, C. E., and D. H. Vickers. 1971. Variation in the elemental content of Eichhornia crassipes. Hydrobiol. 38(3-4):409-414.

20. Brooks, A. A., R. D. Ellison, D. E. Fields, D. D. Huff, R. J. Luxmoore, J. B. Mankin, M. T. Mills, J. K. Munro, M. R. Patterson, R. J. Raridon, M. Reeves, T. C. Tucker, W. Van Winkle, and S. B. Watson. 1974. Development of a unified transport model for toxic materials. Pages 43-91 in Ecology and analys is of trace contaminants-- Progress report, January 1973September 1973, ORNL-NSF-EATC-6. Oak Ridge National Laboratory, Oak Ridge, TN.

21. Brown, B. E. 1977. Effects of mine drainage on the River Hayle, Cornwall. A) Factors affecting concentrations of copper, zinc and iron in water, sediments and dominant invertebrate fauna. Hydrobiol. 52: 221-233.

22. Bryan, G. W. 1967. Zinc regulation in the freshwater crayfish (including some comparative copper analyses). J. Exp. Bio1. 46:281-296.

23. Bulthius, D. A., J. F. Craig, and C. D. McNabb. 1973. Metal dynamics in municipal stabilization ponds. Pages 127-135 in D. D. Hemphill (ed.), Severth Annual Conference on Trace Substances in Environmental Health, Vol. VII. Univ. of Missouri, Columbia.

24. Cairns, J. Jr., R. E. Sparks, and W. T. waller. 1973. The relation between continuous biological monitoring and water quality standards for chronic exposure. Pages 383-402 in G. E. Glass (ed.), Bioassay techniques and environmental chemistry. Ann Arbor Sci. Publ., Inc., Ann Arbor, MI.

25. Carbonneau, M., and J. L. Tremblay. 1972. Study of the role of Scirpus americanus in depolluting waters contaminated with heavy metals. Naturaliste Canadian 99(5):523-532.
26. Cearley, J. E., and R. L. Coleman. 1973. Cadmium toxicity and accumulation in southern Naiad. Bull. Environ. Contam. Toxicol. 9(2):100-101.

27. Chapman, W. H., H. L. Fisher, and M. W. Pratt. 1968. Concentration factors of chemical elements in edible aquatic organisms, UCRL-50564. Lawrence Radiation Laboratory, University of California, Livermore. $50 \mathrm{pp}$.

28. Chappe11, W. R. 1975. Transport and biological effects of molybdenum in the environment. Pages 167-188 in P. A. Krenkel (ed.), Heavy metals in the aquatic environment, An international conference. Pergamon Press, Oxford, England.

29. Cheremisinoff, P., and Y. Habib. 1972. Cadmium, chromium, lead, and mercuryplenary account for water pollution. Pt. I, Occurrence, toxicity, and detection. Water Sewage Works 119(7):73-74, 78, 80-86.

30. Coleman, R. D., R. L. Colement, and E. L. Rice. 1971. Zinc and cobalt bioconcentration and toxicity in selected algal species. Botan. Gazette 132:102-109.

31. Copel and, R. A., and J. C. Ayers. 1972. Trace element distribution in water, sediment, phytoplankton, zooplankton and benthos of Lake Michigan: A baseline study with calculations of concentration factors and buildup of radioisotopes in the food web. Special report no. 1. Environmental Research Group, Inc., Ann Arbor, MI. $271 \mathrm{pp}$.

32. Copeland, R. A., R. H. Beethe, and W. W. Prater. 1973. Trace element distribution in Lake Michigan fish: A baseline study with calculations of concentration factors and equilibrium radioisotope distributions. Environmental Research Group, Inc., Ann Arbor, MI. 143 pp.

33. Copenhaver, E. D., G. U. UTrikson, L. T. Newman, and R. I. Van Hook, Jr. 1973. Arsenic in the environment, An annotated bibliography. ORNL-EIS-73-16. Oak Ridge National Laboratory, Oak Ridge, TN. 304 pp.

34. Cowgi11, U. M. 1973. Biogeochemistry of the rare-earth elements in aquatic macrophytes of Linsley Pond, North Branford, Connecticut. Geochim. Cosmochim. Acta $37: 2329-2345$. 
35. Cowgill, U. M. 1973. Biogeochemical cycles for the chemical elements in Nymphae odorata ait. and the aphid Rhopalos ipnum nympheae (L.) living in Linsley Pond. Sci. Total Environ. $2: 259-303$

36. Cowgill, U. M. 1976. The effect of the thermal regime on the annual distribution of selected elements in Linsley Pond (North Branford, Connecticut). Pages 731-741 in J. 0. Nriagu (ed.), Environmental biogeochemistry, Vol. 2: Metals transfer and ecological mass balance. Ann Arbor Sci. Publ., Inc., Ann Arbor, MI.

37. Cushing, C. E., and D. G. Watson. 1973. Trace element analyses of whitefish. Pages 6.14-6.15 in Pacific Northwest Laboratory annuaT report for 1972 . BNWL-1750, Pt. 2. Battelle, Richland, WA.

38. Cushing, C. E., and L. A. Rancitelli. 1972. Trace element analysis of Columbia River water and phytoplankton. Northwest Sci. 46(2): 115-121.

39. De Groot, A. J., and E. Allersma. 1973. Field observations on the transport of heavy metals in sediments. Pages 85-97 in $P$. A. Krenkel (ed.), Heavy metals in the aquatic environment, An international conference. Pergamon Press, Oxford, England.

40. Delisle, C. E., B. Hummel, and K. G. Wheeland. 1975. Uptake of heavy metals from sediment by fish. Pages 821-827 in T. C. Hutchinson (ed.), Symp. proc. International Conference on Heavy Metals in the Environment, Vol. II, Pt. 2. Institute for Environmental Studies, University of Toronto, Ontario.

41. Dietz, $F$. 1972. The enrichment of heavy metals in submerged plants. Paper no. 4 in Proc. Sixth International Conference on Water Pollution Research. Ruhrverband, Essen, W. Germany. $8 \mathrm{pp}$.

42. Oreesen, D. R., E. S. Gladney, J. W. Owens, B. L. Perkins, C. L. We inke, and L. E. Wangen. 1977. Comparison of levels of trace elements extracted from fly ash and levels found in effluent waters from a coal-fired power plant. Environ. Sci. and Technol. 11(10): 1017-1019.

43. Drifmeyer, J. E., and W. E. Odum. 1975. Lead, zinc, and manganese, in dredge-soil pond ecosystems. Environ. Conservation $2(1): 39-45$.
44. Drummond, R. A., W. A. Spoor, and G. F. 0lson. 1973. Short-term indicators of sublethal effects of copper on brook trout, Salvelinus fontinalis. J. Fish. Res. Board Can. 30(5):698-701.

45. Elder, J. F. 1975. Complexation side reactions involving trace metals in natural water systems. Limnol. Oceanogr. $20(1): 96-102$.

46. Elwood, J. W., S. G. Hildebrand, and J. J. Beauchamp. 1976. Contribution of gut contents to the concentration and body burden of elements in Tipula spp. from a spring fed stream. J. Fish. Res. Board Can. 33(9):1930-1938.

47. Empain, A. 1976. The use of aquatic bryophytes as tracers for heavy metals contamination of fresh waters. Mem. Soc. R. Bot. Belg. 7:141-156. (French.)

48. Enk. M. D., and B. J. Mathis. 1977. Distribution of cadmium and lead in a stream ecosystem. Hydrobiol. 52:153-158.

49. Ernst, W. H. 0. 1975. Physiology of heavy metal resistance in plants. Pages 121-136 in T. C. Hutchinson (ed.), Symp. proc. International Conference on Heavy Metals in the Environment, Vol. II, Pt. 1. Institute for Environmental Studies, University of Toronto, Ontario.

50. Friedman, B. A., and P. R. Dugan. 1968. Concentration and accumulation of metallic ions by the bacterium zoogloea. Dev. Ind. Microbiol. 9:381-388.

51. Galbraith, J. H., R. E. Williams, and P. L. Siems. 1972.' Migration and leaching of metals from old mine tailings deposits. Ground Water 10(3):33-44.

52. Garten, C. T., Jr. 1976. Correlations between concentrations of elements in plants. Nature 261:686-688.

53. Gibbs, R. J. 1973. Mechanisms of trace metal transport in rivers. Sci. 180:71-73.

54. Gilluly, R. H. 1970. Trace elements in air and water. Sci. News 97:538-539.

55. Gladney, E. S. 1974. Trace element emissions of coal-fired power plants: A study of the Chalk Point Electric Generating Station. University Microfilms International. Ph.D. Thesis. University of Maryland. Ann Arbor, MI. 
56. Great Lakes Laboratory. 1971. Chromium, cadmium, arsenic, selenium, mercury and aquatic life: A brief literature review. Special report no. 9. Great Lakes Laboratory, State University College, Buffalo, NY. 23 pp.

57. Grieve, D. A., and W. K. Fletcher. 1976. Heavy metals in deltaic sediments of the Fraser River, British Columbia. Can. J. Earth Sci. 13:1683-1693.

58. Hahne, H. C. H., and W. Kroontje. 1973. Significance of $\mathrm{pH}$ and chloride concentration on behavior of heavy metal pollutants: mercury (II), cadmium (II), zinc (II), and lead (II). J. Environ. Quality 2(4):444-450.

59. Hakanson, L., and T. Ahl. 1975. The distribution of heavy metals in the surficial sediments of Lake Vattern, Sweden. Pages 765-783 in T. C. Hutchinson (ed.), Symp. proc. International Conference on Heavy Metals in the Environment, Vol. II, Pt. 2. Institute for Environmental Studies, University of Toronto, Ontario.

60. Hammond, P. B. 1973. Metabolism and metabolic action of lead and other heavy metals. Clin. Toxicol. 6(3):353-365.

61. Hi17, J. M., and G. R. Helz. 1973. Copper and zinc in estuarine waters near a coal-fired electric power plant. Correlation with oyster greening. Environ. Lett. $5(3): 165-174$

62. Hutchinson, T. C., and H. Czyrska. 1972. Cadmium and zine toxicity and synergism to floating aquatic plants. Water Pollution Research in Canada, Institute of Environmental Science and Engineering, Publ. No. EI $-3: 59-65$.

63. Hutchinson, T. C., A. Fedorenko, J. Fitchko, A. Kuja, J. Van Loon and J. Lichwa. 1976. Movement and compartmentation of nickel and copper in an aquatic ecosystem. Pages 565-585 in J. 0. Nriagu (ed.), Environmental biogeochemistry, Vol. II. Ann Arbor Sci. Publ., Inc., Ann Arbor, MI.

64. Jennett, J. C. and B. G. Wixson. 1975. The new lead belt: Aquatic metal-pathwayscontrol. Pages 247-255 in $T$. C. Hutchinson (ed.), Symp. proc. Interñational Conference on Heavy Metals in the Environment, Vol. II, Pt. 1. Institute for Environmental Studies, University of Toronto, Ontario.
65. Kaakinan, J. W. 1974. Trace element study in a pulverized-coal-fired power plant. Ph.D. dissertation, University of Colorado, Boulder.

66. Kaakinan, J. W., and R. M. Jorden. 1973. Determination of a trace element mass balance for a coal-fired power plant. Pages 165-184 in Proc. First Annual NSF-RANN Trace Contaminants Conference. TIC, Oak Ridge, TN.

67. Kaakinan, J. H., R. M. Jorden, M. H. Lawasani, and R. R. West. 1975. Trace elements fate in a coal-fired power plant. Environ. Sci. Technol. $g(9): 862-869$.

68. Katz, B. G., and D. D. Runnells. 1974. The ability of selected soils to remove molybdenum from industrial wastewaters. Pages 216-223 in Proc. Second Annual NSF-RANN Trace Contaminants Conference. NTIS, Springfield, VA.

69. Kerfoot, W. 3., and S. A. Jacobs. 1976. Cadmium accruai in combined wastewater treatment-aquaculture system. Environ. Sci. Technol. 10(7):662-667.

70. Klein, D. H., and P. Russell. 1973. Heavy metals: fallout around a power plant. Environ. Sci. Technol. $7(4): 357-358$.

71. Kneip, T. J., R. Hernandez, and G. Ré. 1974. Cadmium in an aquatic ecosystem: transport and distribution. Pages 279-282 in Proc. Second Annual NSF-RANN Trace Contaminants Conference. NTIS, Springfield, VA.

72. Kneip, T. J. and G. J. Lauer. 1973. Trace metal concentration factors in aquatic ecosystems. Pages 43-62 in Chemical analys is of the environment and other modern techniques. Plenum Press, New York, London.

73. Kobayashi, J., F. Murii, S. Muramoto, S. Nakashima, H. Teraoka, and S. Horie. 1976. Distribution of arsenic, cadmium, lead, zinc, copper, manganese, and iron contained in the bottom sediment of Lake Biwa. Ber. Ohara Inst. Landwirtsch. Biol., Okayama University 16(4):147-163.

74. Kopp, J. F., and R. C. Kroner. 1967. Trace metals in waters of the United States. Federal Water Pollution Control Administration, Division of Pollution Surveillance, Cincinnati, Ohio. 212 pp. 
75. Kubota, J., E. L. Mills, and R. T. Oglesby. 1974. Lead, $\mathrm{Cd}, \mathrm{Zn}, \mathrm{Cu}$, and $\mathrm{Co}$ in streams and lake waters of Cavuga Lake Basin, New York. Environ. Sci. Technol. $8(3): 243-248$.

76. Lagerwerff, J. V. 1974. Current research in heavy metals in soil, sediment and water: January 1973-0ctober 1974. Pages 16-47 in Proc. Second Annual NSF-RANN Trace Contaminants Conference. NTIS, Springfield, VA.

77. Lasheen, M. R. 1974. Factors influencing metal uptake and release by sediments in aquatic environments. Ph.D. Thesis, University of Michigan.

78. Laskowske, N., T. H. Kost, D. Pommerenke, A. Schafer, and H. J. Tobschall. 1977. Abundance and distribution of some heavy metals in recent sediments of the highly polluted limnic-fluviatile ecosystem near Mainz, West Germany. Pages 587-595 in $\mathrm{J}$. 0 . Nriagu (ed.), Environmental biogeochemistry, Vol. II. Ann Arbor Sci. Publ., Inc. Ann Arbor, MI.

79. Lassiter, R. R. 1975. Modeling dynamics of biological and chemical components of aquatic ecosystems. NTIS, Springfield, VA.

80. Lasz10, F., P. Literathy, and P. Benedek. 1975. Heavy metals pollution in the Sajo River, Hungary. Pages 923-931 in T. C. Hutchinson (ed.), Symp. proc. International Conference on Heavy Metals in the Environment, Vol. II, Pt. 2. Institute for Environmental Studies, University of Toronto, Ontario.

31. Lee, G. F. 1975. Role of hydrous metal oxides in the transport of heavy metals in the environment. Pages 137-147 in P. A. Krenkel (ed.), Heavy metals in the aquatic environment, An international conference. Pergamon Press, Oxford, England.

82. Lee, G. F., J. M. Lopez, and G. M. Mariani. 1975. Leaching and bioassay studies on the significance of heavy metals in dredged sediments. Pages 731-764 in T. C. Hutchinson (ed.), Symp. proc. International Conference on Heavy Metals in the Environment, Vol. II, Pt. 2. Institute for Environmental Studies, University of Toronto, Ontario.
83. Leland, H. V. 1975. Distribution of solute and particulate trace elements in southern Lake Michigan. Pages 709-730 in T. C. Hutchinson (ed.), Symp. proc. International Conference on Heavy Metals in the Environment, Vol. II, Pt. 2, Institute for Environmental Studies, University of Toronto, Ontario.

84. Leland, H. V., E. D. Copenhaver, and L. S. Corrill. 1975. Heavy metals and other trace metals. J. Water Pollut. Control Fed. 46(6):1452-1576.

85. Leland, H. V., and S. S. Shukla. 1974. Factors affecting distribution of lead and other trace elements in sediments of southern Lake Michigan. Pages 89-129 in P. C. Singer (ed.), Trace metals and metal-organic interactions in natural waters. Ann Arbor Sci. Publ., Inc., Ann Arbor, MI.

86. Lemons, J. D., and G. S. Kennington. 1976. Distribution and natural levels of related metals in a trophic pathway, ICP-1095. NTIS, Springfield, VA. $50 \mathrm{pp}$.

87. Lerman, A., and C. W. Childs. 1974. Metal-organic complexes in natural waters: control of distribution of thermodynamic, kinetic and physical factors. Pages 201-236 in Trace metals and metal-organic interactions in natural waters. Ann Arbor Sci. Publ., Inc., Ann Arbor, MI.

88. Lesaca, R. M. 1975. Monitoring of heavy metals in Phillippine rivers, bay waters and lakes. Pages 285-307 in T. C. Hutchinson (ed.), Symp. proc. International Conference on Heavy Metals in the Environment, Vol. II, Pt. 1. Institute for Environmental Studies, University of Toronto, Ontario.

89. Literathy, P., and F. Laszlo. 1977. Uptake and release of heavy metals in the bottom silt of recipients. Pages 403-409 in $H$. L. Golterman (ed.), Interactions between sediments and fresh water. Junk Publ., The Hague, Nether lands.

90. Lucas, H. F., Jr., D. N. Edgington, and P. J. Colby. 1970. Concentrations of trace elements in Great Lakes fishes. J. Fish Res. Board Can. 27(4):677-684. 
91. Luxmore, R. J., D. D. Huff, and K. R. Dixon. 1974. Soil-plant-water effects on uptake and movement of contaminants. Pages 321-324 in Proc. Second Annual NSF-RANN Trace Contaminants Conference. NTIS, Springfield, VA.

92. Lyon, W. S. 1977. Trace element measurements at the coal-fired steam plant. CRC Press, Cleveland, OH. 136 pp.

93. Mathis, B. J., and T. F. Cummings. 1973. Selected metals in sediments, water, and biota in the Illino is River. J. Water Pollut. Control Fed. 45(7):1573-1583.

94. Math is, B. J., T. F. Cummings, M. Gower, M. Taylor, and C. King. 1977. Dynamics of manganese, cadmium, and lead in experimental power plant ponds. UILU-WRC-770125. University of Illino is Water Resources Center, Urbana. 62 pp.

95. Mayer, A. M., and E. Gorham. 1951. The iron and manganese content of some plants present in the natural vegetation of the English Lake district. Ann. Botany 15(50): 247-263.

96. McIntosh, A. N., and T. Peyton. 1974. Distribution and dynamics of trace elements from urban industrial fallout in a closed aquatic ecosystem. Page 230 in Proc. Second Annual NSF-RANN Trace Contaminants Conference. NTIS, Springfield, VA.

97. Medine, A. J., D. B. Porcella, and P. A. Cowan. 1977. Microcosm dynamics and response to a heavy metal loading in a Lake Powell sediment-water-gas ecosystem. Utah State University in Cooperation with USU Foundation, Logan.

98. Merlini, M., F. A. Argentesi, A. Berg, B. Brazzelli, B. Oregion $i$, and $G$. Pozzi. 1973. The biological pathway of zinc $(65 \mathrm{Zn})$ in freshwater fish and its alteration by heavy metals. Pages 285-306 in D. J. Nelson (ed.), Radionuclides in ecosystems, Proc. national symposium held at Oak Ridge, Tennessee. NTIS, Springfield, VA.

99. Merlini, M., and G. Pozzi. 1977. Lead and freshwater fishes. Pt. 2, I on ic lead accumulation. Environ. Pollut. 13:119-126.
100. Merlini, M., 0. Ravera, and C. Bigliocca. 1969. Nondestructive determination of elements in specific freshwater microplankton by activation analysis. Pages 475-481 in J. R. Devoe (ed.), Modern trends in activation analysis, Vol. 1. National Bureau of Standards. Washington, DC.

101. Miettinen, J. K. 1975. The accumulation and excretion of heavy metals in organisms. Pages 155-162 in P. A. Krenkel (ed.), Heavy metals in the aquatic environment, An international conference. Pergamon Press, Oxford, England.

102. Montgomery, A. C., and M. J. Stiff. 1971. Differentiation of chemical states of toxic species, especially cyanide and copper, in water. Pages 375-379 in Proc. International Symposium on Identification and Measurement of Environmentai Pollutants. Ottawa, Ontario.

103. Myttenaere, C., M. Merlini, R. Bittel, P. Dabin, and J. M. Mousny. 1975. Study of the influence of cadmium on the transfer of zinc -65 in an ecosystem irrigated by submersion (irrigated rice field). Pages 39-47 in Impacts of nuclear releases into the aquatic environment. Comission of the European Communities, Ispra, Italy.

104. Namminga, H., and J. Wilhm. 1977. Heavy metals in water, sediments, and chironomids. J. Water Pollut. Control Fed. 49(7):1725-1731.

105. Natusch, D. F. S., C. F. Bauer, H. Matusiewicz, C. A. Evans, J. Baker, A. Loh, R. W. Linton, and P. K. Hopke. Characterization of trace elements in $f l y$ ash. Pages 553-575 in T. C. Hutchinson (ed.), Symp. proc. International Conference on Heavy Metals in the Environment, Vol. II, Pt. 2. Institute for Environmental Studies, University of Toronto, Ontario.

106. Perhac, R. M. 1972. Distribution of cadmium, cobalt, copper, iron, manganese, nickel, lead, and zinc in dissolved and particulate solids from two streams in Tennessee. J. Hydrol. 15(3):177-186.

107. Peterson, P. J. 1975. Element accumulation by plants and their tolerance of toxic mineral soils. Pages 39-54 in T. C. Hutchinson (ed.), Symp. proc. International Conference on Heavy Metals in the Environ ment, Vol. II, Pt. 1. Institute for Environmental Studies, University of Toronto, Ontario. 
108. Peyton, T., A. McIntosh, V. Anderson, and K. Yost. 1976. Aerial input of heavy metals into an aquatic ecosystem. Water, Air and Soil Pollut. 5:443-451.

109. Poldoski, J. E., and G. E. Glass. 1975. Considerations of trace element chemistry for streams in the Minnesota-Ontar io border area. Pages 901-921 in T. C. Hutchinson (ed.), Symp. proc. International Conference on Heavy Metals in the Environment, Vol. II, Pt. 2. Institute for Environmental Studies, University of Toronto, Ontario.

110. Rabe, F. W., and S. B. Bauer. 1977. Heavy metals in lakes of the Coeur d'Alene River Valley, Idaho. Northwest Sci. $5(3): 183-197$.

111. Raridon, R. J., and A. W. Andren. 1975. Computer simulation of trace metal transport. Pages 321-330 in T. C. Hutchinson (ed.), Symp. proc. Internationa 1 Conference on Heavy Metals in the Environment, Vol. II, Pt. 1. Institute for Environmental Studies, University of Toronto, Ontario.

112. Reuter, J. H., and E. M. Perdue. 1977. Importance of heavy metal-organic matter interactions in natural waters. Geochim. Cosmochim. Acta 41:325-334.

113. Rickert, D. A., V. C. Kennedy, S. W. Mckenzie, and W. G. Hines. 1977. A synoptic survey of trace metals in bottom sediments of the Willamette River, Oregon. U. S. Geological Survey Circular 715-F. U. S. Government Printing Office, Washington, $\mathrm{OC} .27 \mathrm{pp}$.

114. Sandholm, M., H. E. Oks anen, and L. Pesonen. 1973. Uptake of selenium by aquatic organisms. Limnol. Oceanogr. $18(2): 496-499$.

115. Sche11, H. R., and R. S. Barnes. 1974. Lead and mercury in the aquatic environment of western Washington State. Pages 129-165 in A. J. Rubin (ed.), Aqueous-environmental chemistry of metals.

116. Schneider, R. F. 1971. The impact of various heavy metals on the aquatic environment. NTIS, Springfield, VA.
117. Schwitzgebel, K., F. B. Meserole, R. G. 01 dham, R. A. Magee, F. G. Mesich, and T. L. Thoem. Trace element discharge from coal-fired power plants. Pages 533-551 in T. C. Hutchinson (ed.), Symp. proc. International Conference on Heavy Metals in the Environment, Vol. II, Pt. 2. Institute for Environmental Studies, University of Toronto, Ontario.

118. Sidle, R. C., J. E. Hook, and L. T. Kardos. 1977. Accumulation of heavy metals in soils from extended wastewater irrigation. J. Water Pollut. Control Fed. $49(2): 311-318$.

119. Sidle, R. C., and L. T. Kardos. 1976. Heavy metal relationships in the Penn State "living filter" system. Pages 249-260 in R. C. Loehr (ed.), Proc. 1976 Corne 11 Āgricultural Waste Management Conference, Ann Arbor Sci. Pub1., Inc., Ann Arbor, MI.

120. Smal1, E., and J. D. Gaynor. 1975. Comparative concentrations of twelve elements in substrates and leaves of Scirpus validus and other aquatic plant species in a sewage lagoon and in unpolluted habitats. Canadian Field-Naturalist $89: 41-45$

121. Smith, K. E., and W. L. Anderson. 1977. Trace element studies at Lake Sangchris: Selected trace metals in lake sediment, air-borne particulate matter, and macrophytes. Pages 5.1-5.31 in Annual report for fiscal year 1976, Lake Sangchris Project. Illino is Natural History Survey, Urbana, IL.

122. Södergren, S. 1976. Ecologica 7 effects of a heavy metal discharge in the Salmon River. Pages 91-131 in Report no. 55, Fishery Board of Sweden. Institute of Freshwater Research, Drottingholm, Sweden.

123. Stokes, P. M. 1975. Adaptation of green algae to high levels of copper and nickel in aquatic environments. Pages 137-154 in T. C. Hutchinson (ed.), Symp. proc. International Conference on Heavy Metals in the Environment, Vol. II, Pt. 1. Institute for Environmental Studies, University of Toronto, Ontario.

124. Stokes, P. 1975. Uptake and accumulation of copper and nickel by metal-tolerant strains of scenedesmus. Verh. Int. Verein. Theor. Angew. LimnoT. 19:2128-2137.

125. Sylva, R. N. 1976. The environmental chemistry of copper (II) in aquatic ecosystems. Water Resourc. Res. 10:789-792. 
126. Terhaar, C. J., W. S. Ewe 1l, S. P. Dziuba, W. W. White, and P. J. Murphy. 1977. A laboratory model for evaluating the behaviour of heavy metals in an aquatic environment. Water Resourc. Res. 11:101-110.

127. Theis, T. L. 1976. Potential trace metal contamination of water resources through the disposal of fly ash. Notre Dame University, Notre Dame, IN. NTIS, Springfield, VA. $21 \mathrm{pp}$.

128. The is, T. L., and P. C. Singer. 1974. The stabilization of ferrous iron by organic compounds in natural waters. Pages 303-320 in P. C. Singer (ed.), Trace metals and metaT-organic interactions in natural waters. Ann Arbor Sci. Publ., Inc., Ann Arbor, MI.

129. Thomas, N. A. 1975. Accumulation and transport of energy related pollutants by benthos. Page 361-368 in Proc. Second Federal Conference on the Great Lakes. Public Information Office, Great Lakes Basin Commission, Ann Arbor, MI.

130. Thomas, R. L., J. M. Jacquet, and A. Mudroch. 1975. Sedimentation processes and associated changes in surface sediment trace meta $i$ concentrations in Lake St. Clair, 1970-1974. Pages 691-708 in T. C. Hutchinson (ed.), Symp. proc. International Conference on Heavy Metals in the Environment, Vol. II, Pt. 2. Institute for Environmental Studies, University of Toronto, Ontario.

131. Thompson, S. E., C. A. Burton, D. J. Quinn, and Y. C. Ng, 1972. Concentration factors of chemical elements in edible aquatic organisms. UCRL-50564, Rev. 1. Lawrence Livermore Laboratory, University of California, Livermore. $77 \mathrm{pp}$.

132. Thornton, I., and J. S. Webb. 1973. Environmental geochemistry: Some recent studies in the United Kingdom. Pages 89-98 in D. Hemphill (ed.), Proc. Seventh Annual Conference on Trace Substances in Environmental Health. University of Missouri, Columbia.

133. Thurston, R. V., and R. C. Russo. 1976. Fish and invertebrate bioassays and bioaccumulation studies. Pages 401-411 in Toxic effects on the aquatic biota from coal and oil shale development: Progress report, yr. 1. Natural Resource Ecology Laboratory, Colorado State University, Fort collins.
134. Trollope, D. R., and B. Evans, 1976. Concentrations of copper, iron, lead, nickel and zinc in freshwater algal blooms. Environ. Pollut. 11:109-116.

135. Uthe, J. F., and E. G. Bligh. 1971. Preliminary survey of heavy metal contamination of Canadian freshwater fish. J. Fish. Res. Board Can. $28(5): 786-788$

136. Van der Borght, 0., and S. Van Puymbroeck. 1971. Kinetics of the direct uptake of $\mathrm{Ca}$ and $\mathrm{Sr}$ ions from water by freshwater gastropods. Environ. Physiol. 1(2):83-95.

137. Van Hook, R. I., W. F. Harris, G. S. Henderson, and D. E. Reichle. 1974. Trace element distributions on walker Branch Watershed. pp. 165-171 in Trace contaminants in the environment, Proc. Second Annual NSF-RANN Trace Contaminants Conference. NTIS, Springfield, VA.

138. Van Loon, J. C. 1975. How useful are environmental chemical data? Pages 349-355 in T. C. Hutchinson (ed.), Symp. proc. International Conference on Heavy Metals in the Environment, Vol. I. Institute for Environmental Studies, University of Toronto, Ontario.

139. Varenko, N. I., and I. P. Lub'yanov. 1973. Accumulation of trace elements (Mn, $\mathrm{Zn}, \mathrm{Cu}$, and $\mathrm{Co}$ ) by some hydrophytes of the Dnieprodzerzhinsk and Zaporozhye reservoirs. Ukr. Bot. Zh. 30(2):163-168.

140. Vaughan, B. E., K. H. Abel, D. A. Cataldo, J. M. Hales, C. E. Hane, L. A. Rancitelli, R. C. Routson, R. E. Wildung, and E. G. Wolf. 1975. Review of potential impact on health and environmental quality from metals entering the environment as a result of coal utilization. Battelle, Richland, WA. $75 \mathrm{pp}$.

141. WAPORA, Inc. 1973. Trace metal analyses and growth rate determination of selected fish in Lake Coffeen. Submitted to Central Illinois Public Service Company, Springfield. Submitted by WAPORA, Inc., Charleston, IL. 13 pp.

142. Wewerka, E. M., J. M. 'Nilliams, and P. L. Wanek. 1976. Assessment and control of environmental contamination from trace elements in coal processing wastes. NTIS, Springfield, VA. $7 \mathrm{pp}$. 
143. Whitehead, N. E., and R. R. Brooks. 1969. Aquatic bryophytes as indicators of uranium mineralization. Bryologist 72:501-507.

144. Whitton, B. A., and P. J. Say. 1975. Heavy metals. Pages $286-311$ in $B$. A. Whitton (ed.), River ecology. University of California, Berkeley.

145. Williams, L. G., J. C. Joyce, and J. T. Monk, Jr. 1973. Stream-velocity effects on the heavy-metal concentrations. J. Am. Water Works Assoc. 65(4):275-279.

146. Williams, S. L., D. B. Aulenbach, and N. L. Clesceri. 1974. Sources and distribution of trace metals in aquatic environments. Pages 77-127 in A. J. Rubin, Aqueous-environmental chemistry of metals. Ann Arbor Sci. Pubi., Ann Arbor, MI.

147. Wolfe, D. A., and T. R. Rice. 1972. Cycling of elements in estuaries. Fish. Bul1. 70:959-972.
148. Wood, J. M. 1973. Metabolic cycles for toxic elements in aqueous systems. Rev. Int. Oceanogr. Med. 31-32:7-16.

149. Wood, J. M. 1975. Metabolic cycles for toxic elements in the environment: A study of kinetics and mechanism. Pages 105-112 in P. A. Krenkel (ed.), Heavy metals in the aquatic environment, An international conference. Pergamon Press, 0xford, Eng 1 and.

150. Wood, J. M., H. J. Sega11, W. P. Ridley, A. Cheh, W. Chudyk, and J. S. Thayer. 1975. Metabolic cycles for toxic effluents in the environment. Pages 49-68 in T. C. Hutchinson (ed.), Symp. proc. International Conference on Heavy Metals in the Environment. Institute for Environmental Studies, University of Toronto, Ontario.

151. Yager, C. M. 1966. Uptake of heavy metal ions by Taphius glabratus, a snail host of Schistosoma mansoni. Exp. Parasitol. $19(2): 174-182$. 
9.1: ?:

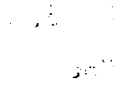


INDEX

\section{Arsenic}

$3,4,15,16,33,37,38,39,42,55,56$, $67,73,83,85,90,105,107,111,113$, $130,132,133,135,137,138,141,148$, 150 .

Boron

$1,15,17,19,42,83,133$.

\section{Cadmium}

$4,5,6,8,9,13,15,16,23,25,26,29$, $37,39,40,42,47,48,49,56,58,62,69$, $70,71,73,75,76,77,78,80,82,83,88$, $90,91,93,94,96,97,101,103,105,106$, $108,109,110,111,112,113,118,119$, $121,129,130,132,136,137,138,140$, $141,145,147,151$.

Chromium

$3,4,6,8,9,11,23,29,31,32,37,38$, $39,46,47,53,56,59,70,82,83,85,88$, $90,93,97,102,104,105,107,111,113$, $121,130,140,145,147$.

\section{Copper}

$1,3,4,5,6,7,9,10,12,13,15,16$, $18,19,21,22,23,38,39,40,41,44,47$, $49,53,54,57,59,61,63,67,70,72,73$, $75,76,77,78,82,83,85,86,88,90,91$, $93,102,104,105,106,109,110,111,112$, $113,118,119,120,121,122,123,124,125$, $129,130,133,134,135,139,140,141$, 145,147 .

\section{Iron}

$1,6,7,11,15,16,19,21,23,32,37$, $38,41,47,51,53,54,57,67,70,73,82$, $83,88,95,96,105,106,108,111,112$, $120,122,128,134,138,145$.

\section{Lead}

$5,6,7,9,10,15,16,25,29,39,40,41$, $43,47,48,49,55,57,58,59,60,64,67$, $73,75,76,77,82,83,85,86,88,91,93$, $94,96,97,99,101,104,105,106,108$ $109,110,111,112,113,115,118,129$, $130,134,135,137,138,140,150$.

\section{Lithium}

36 .

\section{Manganese}

$1,4,6,7,10,11,15,16,18,19,23,32$, $38,41,43,46,47,51,53,54,57,72,73$, $80,82,83,88,94,95,100,105,106,111$. $139,140,145,147$.

\section{Molybdenum}

$19,28,36,43,59,67,68,83,88,105$, $130,132,140,147$.

\section{Nickel}

$3,4,6,7,15,16,23,39,41,47,53,54$, $57,59,63,70,78,82,83,85,88,93$, $105,106,107,109,111,118,121,122$, $123,124,130,134,140,147$.

\section{Selenium}

$37,38,42,46,54,55,56,67,90,105$, $114,133,140,150$.

\section{Silver}

$4,32,36,37,38,59,70,78,88,113$, 126,130 .

\section{Strontium}

$4,10,16,32,67,83,88,129,136,147$.

\section{Uranium}

$4,15,38,90,105,140,143,144$.

\section{Zinc}

$1,3,4,5,6,7,9,10,12,16,18,19$, $21,22,23,24,30,31,32,37,38,39,40$, $41,43,46,47,49,54,55,57,58,59,61$, $62,67,70,73,75,76,78,80,82,83,85$, $86,88,90,91,93,96,97,98,103,104$,

$105,106,108,109,110,111,112,113$,

$118,119,120,121,122,129,130,132$, $134,135,137,138,139,140,141,145$, 147,151 .

\section{General}

$2,14,20,27,34,35,45,50,52,65,66$, $74,81,84,87,89,92,117,127,131,142$, $146,149$. 


\section{DISTRIBUTION}

No. of

Copies

OFFSITE

A. A. Churm

ERDA Chicago Patent Attorney

9800 South Cass Avenue

Argonne, IL 60439

R. L. Watters

DOE Division of Biomedical and

Environmental Research

Washington, DC 20545

27 DOE Technical Information Center Washington, DC 20545

\section{ONSITE}

DOE - U.S. Department of Energy $\mathrm{RL}$

H. E. Ransom
No. of

Copies

52 Pacific Northwest Laboratory

C. D. Becker

B. W. Compton (4)

C. E. Cushing (25)

R. M. Emery

D. H. Fickeisen

R. F. Foster

M. G. LaRiviere

D. H. McKenzie

T. L. Page

M. J. Schneider

A. J. Scott

J. B. States

J. A. Strand

W. L. Templeton

J. M. Thomas

B. E. Vaughan

R. E. Wildung

W. G. Woodfield

Technical Information (5)

Publishing Coordination (2) 


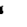

